International Research Journal of Management, IT \& Social Sciences
Available online at https://sloap.org/journals/index.php/irjmis/
Vol. 6 No. 6, November 2019, pages: 118 127
$\begin{aligned} & \text { ISSN: 2395-7492 } \\ & \text { https://doi.org/10.21744/irjmis.v6n6.778 }\end{aligned}$

\title{
Effect of Transformational Leadership and Organizational Culture on Employee Performance Mediated by Job Motivation
}

\author{
G. Ngurah Suteja Putra ${ }^{a}$ \\ I Gusti Ayu Manuati Dewi ${ }^{b}$
}

Article history:

Received: 18 June 2019

Accepted: 30 September 2019

Published: 28 October 2019

\section{Keywords:}

employee;

job motivation;

organizational culture;

performance;

transformational leadership;

\begin{abstract}
This study aims to analyze the effect of transformational leadership and organizational culture on employee performance mediated by job motivation. The population in this study included 134 Civil Servants in the Secretariat of the Bali District/City Election Commission with a total sample of 100 people using the proportional random sampling method. Data analysis techniques were performed using Structural Equation Modeling (SEM) with the Partial Least Square (PLS) approach. Job motivation is able to mediate the relationship between transformational leadership and organizational culture on employee performance partially. The Head of the Secretariat of the KPU of Regency/City in Bali needs to develop a transformational leadership style by providing motivation that inspires subordinates to work better when job motivation increases will be directly proportional to an increase in employee performance. In addition, a strong organizational culture such as information disclosure and participation of all members of the organization in achieving organizational goals can be developed continuously. When job motivation increases, it will encourage employees to improve the quality and timeliness of employees in completing work.
\end{abstract}

2395-7492@ Copyright 2019. The Author. This is an open-access article under the CC BY-SA license (https://creativecommons.org/licenses/by-sa/4.0/) All rights reserved.

Author correspondence:

G. Ngurah Suteja Putra,

Udayana University, Denpasar, Indonesia.

Email address: ngurahsuteja81@gmail.com

\section{Introduction}

In organizing elections, the General Election Commission is inseparable from challenges and obstacles. To answer the challenges and obstacles in the election process, it requires a quality of human resources that is reliable and experienced in the electoral field. In organizing the General Elections, the Chairperson and Members of the KPU are assisted by the KPU Secretary-General to carry out their functions in accordance with the provisions. One of the activities carried out by the Bali Provincial KPU is the Election of the Governor and Deputy Governor of Bali in 2018. Although the

\footnotetext{
a Udayana University, Denpasar, Indonesia

${ }^{\mathrm{b}}$ Udayana University, Denpasar, Indonesia
} 
election process in Bali can be said to be smooth and safe, the internal problems of the Regency / City KPU in Bali as the organizer of the General Election still remain. Employee performance is still an issue that has always been a subject of discussion for leaders in the Regency / City KPU Secretariat throughout Bali. The performance evaluation data measured by Bali Provincial KPU shows that the performance of Regency / City KPU in Bali is still low and not optimal.

There are nine performance assessment indicators used by the Bali Provincial KPU to measure the performance of Regency / City KPUs in Bali in organizing the 2018 Governor and Deputy Governor elections. One of them is the accuracy of sending financial accountability reports, providing election education to the public and quality voter data measured through four indicators, among others, the timeliness of each update stage, innovations in updating, building teamwork in the update stage, and good relations with the stakeholders of the update still show relatively low work results. None of them obtained the maximum value in measuring the performance.

Not yet the maximum performance of the Regency / City KPU above is caused by human resources that have not been maximized at work. Many factors cause this, one of which is leadership. Most employees feel the lack of concern for the leadership of the work problems of his subordinates causes the employee's performance is not optimal. Leaders do not give encouragement that is able to motivate subordinates to work. On the other hand, the KPU is an institution that works collectively, so that all work is done together. But lately, collective culture has begun to weaken and be replaced by individualist cultures. Most employees tend to be selfish and group rather than the interests of the organization as a whole (Krisnanda \& Surya, 2019; Suwandana, 2019).

The performance of employees who have not been maximized needs to be done in-depth studies to uncover and find solutions. Several studies have shown that performance can be influenced by job motivation. According to Omollo (2015), job motivation is a variable that is able to influence performance positively and significantly. In addition, in line with Siregar (2016), which states that job motivation has a positive effect on performance. Besides that, according to Mohamud et al., (2017), in his research stated motivation influences the performance of Hormuud Company employees in Mogadishu Somalia. This means that all employees must be motivated to work and this will improve performance, in this way the productivity and effectiveness of the organization as a whole can be increased. Bagraim \& Werner (2003); Yunita \& Saputra (2019), states that the characteristics of motivated employees are that they always want to come to work, want to be part of a team at work, are interested in helping, supporting others at work, trying harder in their work, and contributing more in organization.

To increase job motivation, leadership has a large enough influence to motivate subordinates to work. One of them is transformational leadership. Transformational leadership style has a role to provide more positive encouragement to their subordinates so that they are motivated to do more than expected (Syaifuddin, 2016). Farid et al., (2014), states that there is a significant positive relationship between transformational leadership and employee motivation. Ullah et al., (2018), also states that the transformational leadership style is able to influence employee motivation by inspiring subordinates.

In addition to transformational leadership, organizational culture is also said to be able to influence employee job motivation. Some researchers state that organizational culture can affect job motivation, according to Mahal (2009), in his research stating that organizational culture is positively related to job motivation, so to increase employee motivation leaders must try to strengthen their organizational culture. This is supported by the research of Anra et al., (2017); Tobing \& Syaiful (2016); Krisnanda \& Surya (2019); and Pramudjono (2015), who stated that organizational culture has a positive and significant influence on job motivation. To assist organizations in increasing motivation is to have a strong organizational culture to support job motivation (Radakovich, 2016).

Other findings also state that in addition to job motivation, transformational leadership can also directly affect employee performance. Applying the right leadership style will give the final result in the form of improving employee performance. Syaifuddin (2016) states, transformational leadership has a significant effect on employee performance. A study in Pakistan that examined the influence between transformational leadership styles and transactional leadership on employee performance, the study stated that there was a significant positive relationship between transformational leadership styles on employee performance compared with transactional leadership (Rasool et al., 2015). In line with what was stated by Caillier (2014), when leaders practice transformational leadership styles employee performance is better than not practicing it, so it can be said that transformational leadership positively influences performance.

In addition to the direct influence between transformational leadership on employee performance, organizational culture is said to have a direct effect on employee performance. This is supported by Narayan (2017), who said that organizational culture can have various impacts on employee performance. A strong organizational culture will encourage employees to improve their performance (Narayan, 2017). Sihombing et al., (2016), states that there is a significant influence of organizational culture on employee performance. Anra et al., (2017), also concluded in his

Putra, G. N. S., \& Dewi, I. G. A. M. (2019). Effect of transformational leadership and organizational culture on employee performance mediated by job motivation. International Research Journal of Management, IT and Social Sciences, 6(6), 118-127. https://doi.org/10.21744/irjmis.v6n6.778 
research that organizational culture directly affects the performance of lecturers at the University of Jambi. The results of the analysis of organizational culture variables explain that culture is a significant factor for improving employee performance, managers in organizations must translate this relationship into action (Sivakami \& Samitha, 2018). However, Bassem \& Saheb (2018), stated a different view that organizational culture does not affect employee performance. This can occur because employees do not fight for the same organizational culture as the organizational culture of the company. The difference in the results of this study is an underlying basis for reexamining the relationship between organizational culture and employee performance.

In addition, there are also previous studies that obtain different findings, namely organizational culture is not directly related to employee performance, but with the addition of mediation variables. The use of job motivation variables as mediating the relationship between organizational culture and employee performance is based on the empirical results of previous studies. Based on the research results of Bangun et al., (2018), job motivation plays a positive and significant mediating variable in explaining the influence of organizational culture on employee performance. Employees who already have a strong organizational culture will be motivated to work, he said, they are able to show performance and work results that are in accordance with the standards set by the company (Kawiana $e t$ al., 2018; Pant \& Yadav, 2016).

\section{Literature Review and Hypothesis}

Research on performance suggests definitions that are consistent with this study. According to Ilham (2018), performance is the result of work both in quality and quantity achieved by an employee in carrying out their duties in accordance with the responsibilities given to him. Employee performance is work performance or work output (output) both quality and quantity achieved by employees per one time period in carrying out their work duties in accordance with the responsibilities given to them. According to Na-Nan \& Chaiprasit (2018), performance indicators are divided into three, among other job quality, job quantity, and job time.

Job motivation is the process of influencing or encouraging within and outside oneself towards a person or workgroup so that they want to carry out their duties properly according to the provisions. When employees have high job motivation, it will lead to an increase in employee performance. Gagné et al., (2010), states that there are 4 (four) indicators of job motivation, namely intrinsic motivation, identified regulation, introjected regulation, and external regulation.

Leadership is the most talked about topic in management. Among leadership theories, nature theory, behavior theory, and contingency theory are called traditional leadership theories, while transformational and transactional theories are called new leadership theories (Rasool et al., 2015). Transformational leadership is all about encouraging others to develop and produce performance that exceeds expected standards. A leader who applies a transformational leadership style is able to inspire others to see the future with optimism, project an ideal vision, and be able to communicate a vision that can be achieved (Syaifuddin, 2016). Meanwhile, transactional leadership is where a leader encourages his subordinates to work by providing resources and rewards in return for motivation, productivity, and task achievement.

Transformational leadership has the ability to bring about changes in the organization's vision, strategy, and culture. Whereas transactional leaders will be more inclined to maintain stability in the organization rather than promoting change. Transformational leadership is felt to be more in line with the conditions of the Regency / City KPU Secretariat in Bali which expects a change towards a better direction than by maintaining stability and current conditions that are not optimal in terms of employee performance. According to Obeidat et al., (2018), there are four indicators in transformational leadership, namely: idealized influence, inspirational motivation, intellectual stimulation, and individualized consideration.

Organizational culture is the values and symbols that are understood and obeyed by all members of the organization (Pawirosumarto, 2016). Strong organizational culture can encourage employees to have high motivation levels of employee motivation to work optimally. According to Ghosh \& Bhupen (2014), there are seven indicators of organizational culture, namely participation, respect for the individual, attitude to risk, action orientation, trust, openness, and power distance.

Hypothesis

H1: Transformational leadership has a significant positive effect on employee performance

$\mathrm{H} 2$ : Organizational culture has a significant positive effect on employee performance

H3: Transformational leadership has a significant positive effect on job motivation 
H4: Organizational culture has a significant positive effect on job motivation

H5: Job motivation has a significant positive effect on employee performance

H6: Job motivation mediates the effect of transformational leadership on employee performance positively and significantly.

H7: Job motivation mediates the effect of organizational culture on employee performance positively and significantly.

\section{Materials and Methods}

The population in this study were all Regency / City KPU Secretariat staff as many as 134 people. The sample is determined based on the Slovin formula with a margin of error of 5\%. Based on this formula the number of samples was 100 people. Determination of the sample in this study using the proportional random sampling method. Questionnaire distribution to the Regency / City KPU Secretariat in Bali which was divided into nine regencies and cities which included: Denpasar, Badung, Tabanan, Jembrana, Buleleng, Bangli, Karangasem, Klungkung, and Gianyar.

The method used in this study is a cross-sectional survey method in which to collect data using a questionnaire or structured questionnaire related to the research variables. The scale used is the Likert Scale, with the highest score variation (5) strongly agree to the smallest score (1) strongly disagree. The analysis used in this study is a quantitative analysis using Structural Equation Modeling (SEM) with the Partial Least Square (PLS) approach.

\section{Results and Discussions}

Evaluation of structural models or inner models is carried out to ensure that structural models are built strong and accurate. Testing can be done by calculating the value of $R$ square $\left(R^{\wedge} 2\right)$ and predictive relevance $\left(Q^{2}\right)$.

The results of the $\mathrm{R}$ Square value in Table 1 . Shows the value of the employee performance variable of 0.687 . This value can explain that $68.7 \%$ of changes in employee performance variables are quite strongly influenced by transformational leadership variables, organizational culture, and job motivation, while $31.3 \%$ of changes are influenced by variables outside the model. In the job motivation variable, $56.6 \%$ of the change is influenced by variables of transformational leadership and organizational culture, and $43.4 \%$ is influenced by variables outside the model.

Table 1

R Square

\begin{tabular}{ll}
\hline Variable & R Square \\
\hline Performance (Y) & 0,687 \\
Job Satisfaction (M) & 0,566 \\
\hline
\end{tabular}

Primary Data, 2019

Based on the acquisition of $\mathrm{R}^{2}$, a calculation can be made of the value of predictive relevance (Q2), with interpretation if $\mathrm{Q}^{2}$ is greater than 0 , then the model can be said to be good and able to explain the phenomenon of performance variables equal to the $\mathrm{Q} 2$ value. Predictive relevance values can be calculated as follows:

$$
\begin{aligned}
\mathrm{Q}^{2}= & 1-\left(1-\llbracket \mathrm{R}_{1}^{2}\right)\left(1-\llbracket \mathrm{R}_{2} \rrbracket^{2}\right) \\
& =1-(1-0,687)(1-0,566) \\
& =1-(0.313)(0.434) \\
& =1-(0.136) \\
& =0.864
\end{aligned}
$$

The results of this calculation indicate that the $\mathrm{Q}^{2}$ value is greater than $0(0.864)$, so the model can be said to be good and has a relevant predictive value of $86.4 \%$. This value interprets that $86.4 \%$ of changes or variations in performance

Putra, G. N. S., \& Dewi, I. G. A. M. (2019). Effect of transformational leadership and organizational culture on employee performance mediated by job motivation. International Research Journal of Management, IT and Social Sciences, 6(6), 118-127. https://doi.org/10.21744/irjmis.v6n6.778 
variables can be explained by the variables used in the study, while the remaining $13.6 \%$ is explained by other variables outside the model.

Hypothesis testing result

The significance of the estimated parameters can be used to see the relationship between variables in the study. To test hypotheses, this is done by looking at the values in the path coefficients presented in Table 2 .

Table 2

Path Coefficients

\begin{tabular}{lllll}
\hline Variable & Path Coefficients & $\mathrm{t}$ Statistics & $\mathrm{p}$ Values & Description \\
\hline Transformational Leadership -> Performance & 0,378 & 2,971 & 0,003 & H1 accepted \\
Org. Cultural -> Performance & 0,259 & 2,193 & 0,029 & H2 accepted \\
Transformational Leadership -> Job Motivation & 0,405 & 3,253 & 0,001 & H3 accepted \\
Org. Cultural -> Job Motivation & 0,426 & 3,528 & 0,000 & H4 accepted \\
Job Motivation -> Performance & 0,300 & 2,765 & 0,006 & H5 accepted \\
\hline
\end{tabular}

Primary Data, 2019

Hypothesis testing is evaluated by looking at the t-statistic value, as well as the p-value. At the t-statistic condition greater than t-table (1.96), and p-value below 0.05, the research hypothesis can be accepted. In Table 2, it is known that the effect of transformational leadership (X1) on employee performance (Y) has a t-statistic value of 2.971 and $\mathrm{p}$ value of 0.003 , then there is a positive and significant effect between transformational leadership (X1) on employee performance (Y), so H1 is accepted. In the influence of organizational culture (X2) on employee performance (Y) has a t-statistic value of 2.193 and p-value of 0.029 , then there is a positive and significant effect between organizational culture (X2) on employee performance (Y), then $\mathrm{H} 2$ is accepted.

The influence of transformational leadership (X1) on job motivation (M) has a t-statistic value of 3.253 and p-value of 0.001 , then there is a positive and significant influence between transformational leadership (X1) on job motivation (M), so that $\mathrm{H} 3$ is accepted. The influence of organizational culture (X2) on job motivation (M) has a t-statistic value of 3.528 and p-value of 0.000 , so there is a positive and significant influence between organizational culture (X2) on job motivation (M), so that $\mathrm{H} 4$ is accepted. The influence of job motivation $(\mathrm{M})$ on employee performance $(\mathrm{Y})$ has a t-statistic value of 2.765 and p-value of 0.006 , then there is a positive and significant effect between job motivation (M) on employee performance (Y), then $\mathrm{H} 5$ is accepted.

\section{The role of job motivation mediation on the effects of transformational leadership on employee performance}

The direct effect test results by including mediation in Table 2 shows that the transformational leadership coefficient value on performance is 0.378 with $t$ statistics value of 2.971 and $p$-value of 0.003 . Job motivation as a mediating variable has a VAF value of $0.244(24.4 \%)$ obtained from the division between indirect effects divided by the total effect $(0.122 / 0.500)$. So it can be concluded that job motivation has a partial mediating role in the relationship between transformational leadership and employee performance, which means transformational leadership is able to influence employee performance directly or indirectly through job motivation. So H6 which states that job motivation acts as a mediator of the relationship between transformational leadership and employee performance is acceptable.

\section{The role of job motivation mediation on the effects of organizational culture on employee performance}

The direct effect test results by including mediation in table 2. show that the coefficient value of organizational culture on performance is 0.259 with $t$ statistics value of 2.193 and p-value 0.029 , so the hypothesis is accepted. Job motivation as a mediating variable has a VAF value of $0.330(33.0 \%)$ obtained from the division between indirect effects divided by the total effect $(0.128 / 0.388)$. It can be concluded that job motivation has a partial mediating role in the relationship between organizational culture and employee performance, which means that organizational culture is able to influence employee performance directly or indirectly through job motivation. So the hypothesis which states that job motivation acts as a mediator of the relationship between organizational culture and employee performance can be accepted. 


\section{The effect of transformational leadership on employee performance}

Hypothesis testing shows that transformational leadership influences employee performance positively and significantly. This means that the better the leader of the Regency / City KPU in Bali applies the transformational leadership style, the better the employee performance will be. Leaders always motivate subordinates and instill confidence that the goals of the organization will be achieved. With an inspiring passion and concern for each individual, leaders can be trusted by their subordinates so that their subordinates will be encouraged to improve their performance. The results of this study are also supported by previous studies, one of which is Syaifuddin (2016), who states that transformational leadership has a positive and significant effect on performance. There is a significant positive relationship between transformational leadership style on performance compared with transactional leadership (Rasool et al., 2015). As stated by Caillier (2014), when leaders practice transformational leadership styles employee performance is better than not practicing it, so that transformational leadership positively influences performance.

\section{The effect of organizational culture on employee performance}

Hypothesis testing results show that organizational culture influences employee performance positively and significantly. That is, the stronger the organizational culture understood and applied by the Regency / City KPU Secretariat Staff in Bali will directly be able to improve their performance. The openness of information that can be accessed by all members of the organization becomes an important point to strengthen organizational culture. The disclosure of information and the involvement of all members of the organization towards the achievement of organizational goals can encourage employee performance improvement in the quality of work and the timeliness of completing work. The results of this study are also supported by previous studies, one of which is Sivakami \& Samitha (2018), which states that culture is a significant factor to improve the performance of employees and managers in organizations must translate this relationship into action. Thuku et al., (2016), states that organizational culture influences employee performance positively and significantly. Organizational culture is the values and beliefs held by an organization, the stronger the culture is believed by members of the organization, the higher the performance of its employees.

\section{The effect of transformational leadership on job motivation}

The results of this study indicate that transformational leadership has a positive and significant effect on job motivation. This means that the better the Chairperson of the Regency / City KPU Secretariat in Bali adopt a transformational leadership style, it will increase employee motivation at work. With the positive encouragement given by the leadership, this work was felt to be able to provide a pleasant experience for the staff of the Regency / City KPU Secretariat in Bali so that motivation within themselves to work better appeared. The results of this study are supported by several previous studies, one of which is Chukwura \& Francisca (2016), transformational leadership styles have a strong positive correlation with employee motivation while destructive and toxic leadership styles negatively impact motivation. Ullah et al., (2018), also states that transformational leadership styles can influence employee motivation by inspiring subordinates.

\section{The effect of organizational culture on job motivation}

The results of this study indicate that there is a positive and significant influence between organizational culture on job motivation. That is, a strong organizational culture will create high job motivation so that it can create a good working atmosphere within the Regency / City KPU Secretariat in Bali. With a strong organizational culture in the Secretariat of Regency / City KPU in Bali felt able to foster motivation in employees who cause employees to work comfortably so that they have high motivation in working. The results of this study are also supported by previous studies one of which is Mahal (2009), in his research stating that organizational culture is positively related to job motivation, so to increase motivation among employee leaders must strive to strengthen organizational culture. In line with previous research, according to Tobing \& Syaiful (2016); Hakim (2012); and Anra et al., (2017), organizational culture has a significant influence on job motivation.

Putra, G. N. S., \& Dewi, I. G. A. M. (2019). Effect of transformational leadership and organizational culture on employee performance mediated by job motivation. International Research Journal of Management, IT and Social

Sciences, 6(6), 118-127. https://doi.org/10.21744/irjmis.v6n6.778 
The effect of job motivation on employee performance

The results of this study indicate that there is a positive and significant effect on job motivation on employee performance. The higher the motivation of Regency / City KPU Secretariat staff in Bali to work, their performance will also increase. When employees find this work interesting and fun and employees give high marks to this work will be able to improve the quality of work and the timeliness of them in completing work. This research is also supported by the results of previous studies namely Hakim (2012), in his research stating that job motivation affects employee performance, the more increased employee motivation will be able to improve employee performance. According to Mohamud et al., (2017), in his study stated that employee motivation affects the performance of Hormuud Company employees in Mogadishu Somalia. This means that all employees must be motivated to improve performance, in this way the overall productivity and effectiveness of the organization can be improved.

\section{Job motivation mediates the effect of transformational leadership on performance}

The results of this study indicate that the job motivation variable has a role as a partial mediation between transformational leadership on employee performance, which means transformational leadership is able to influence employee performance directly or indirectly through job motivation. By giving encouragement from the leadership that includes the important values of the institution, motivation that is able to inspire, encouraging to see the problem from a different perspective, and having a concern for everyone in the organization can affect employee performance improvement. The results of this study are also supported by previous research namely Syafii et al., (2015), states that job motivation positively mediates the effect of transformational leadership on employee performance. Sappe et al., (2016), states the effect of leadership on employee performance through job motivation is meaningful and full of character as an intervening variable.

\section{Job motivation mediates the effect of organizational culture on performance}

The results of this study indicate that the variable job motivation has a role as a partial mediation between organizational culture on employee performance, which means that organizational culture is able to influence employee performance directly or indirectly through job motivation. Information disclosure and involvement of all members of the organization towards the achievement of organizational goals can lead to increased job motivation. When employees feel this job is right and can fulfill their life goals, high motivation will appear to improve employee performance. This research is supported by the empirical results of previous studies. Bangun et al., (2018), the results of his research indicate that the relationship between organizational culture and lecturer/employee performance can be considered indirectly because it is fully mediated by increased lecturer/employee motivation. According to Manggis et al., (2018), job motivation is able to mediate positively and significantly on the indirect effect of organizational culture on employee performance.

\section{Conclusion}

This research shows that the better the leadership of the Regency / City KPU Secretariat in Bali applying the transformational leadership style will encourage direct employee performance improvement. Leaders' beliefs that organizational goals will be achieved provide motivational encouragement that can inspire subordinates to improve their performance as indicated by the quality of work and the timeliness of completing work. In addition, this research shows that when employees are able to understand organizational culture great they will be able to encourage them to improve their performance. Information openness, the participation of all members of the organization in achieving organizational goals and mutual trust between members of the organization creates a strong bond to work collectively, by working collectively employees will be able to improve their performance in terms of quality of work and timeliness of completing work. If employees feel this job is fun and able to fulfill their life goals, they will feel highly motivated to be able to improve their performance. When this high job motivation is able to be developed by the leadership of the Regency / City KPU Secretariat in Bali, the employee's performance in terms of quality of work and timeliness in completing work will increase even more. 


\section{Research Limitation}

This research depends on the results of the questionnaire so that respondents have the potential to give answers that are considered in accordance with certain values that can be accepted in their social environment so that it can distort the average value for each variable. This research was conducted with a cross-sectional time design, with the dynamics of change in each period. In addition, this research can be generalized to the KPU Secretariat only because fluctuating working conditions can change each period in accordance with the activities of the electoral stages that are held.

Conflict of interest statement

The authors declared that they have no competing interests.

Statement of authorship

The authors have a responsibility for the conception and design of the study. The authors have approved the final article.

\section{Acknowledgments}

The authors would like to thank the reviewer for their consideration of the further process of the present paper. Thanks to the editor of IRJMIS for the valuable support, time as well as advice.

Putra, G. N. S., \& Dewi, I. G. A. M. (2019). Effect of transformational leadership and organizational culture on employee performance mediated by job motivation. International Research Journal of Management, IT and Social Sciences, 6(6), 118-127. https://doi.org/10.21744/irjmis.v6n6.778 


\section{References}

AbdiMohamud, S., Ibrahim, A. A., \& Hussein, J. M. (2017). The effect of motivation on employee performance: Case study in Hormuud company in Mogadishu Somalia. International Journal of Development Research, 9(11), 1700917016.

Ahmad, F., Abbas, T., Latif, S., \& Rasheed, A. (2014). Impact of transformational leadership on employee motivation in telecommunication sector. Journal of management policies and practices, 2(2), 11-25.

Anra, Y., \& Yamin, M. (2017). Relationships between lecturer performance, organizational culture, leadership, and achievement motivation. Фopcaüm, 11(2 (eng)).

Bangun, R., Theresia, L., Lahuddin, A. H., \& Ranti, G. (2018). The influence of culture, job satisfaction and motivation on the performance lecturer/employees. In Proceedings of the International Conference on Industrial Engineering and Operations Management (pp. 2541-2552).

Caillier, J. G. (2014). Toward a better understanding of the relationship between transformational leadership, public service motivation, mission valence, and employee performance: A preliminary study. Public Personnel Management, 43(2), 218-239. https://doi.org/10.1177\%2F0091026014528478

Chukwura, F. A. (2016). The Impact of Selected Leadership Styles and Behaviors on Employee Motivation and Job Satisfaction (Doctoral dissertation, University of Maryland University College).

Gagné, M., Forest, J., Gilbert, M. H., Aubé, C., Morin, E., \& Malorni, A. (2010). The motivation at work scale: Validation evidence in two languages. Educational and psychological measurement, 70(4), 628-646. https://doi.org/10.1177\%2F0013164409355698

Ghosh, S., \& Srivastava, B. K. (2014). Construction of a reliable and valid scale for measuring organizational culture. Global Business Review, 15(3), 583-596. https://doi.org/10.1177\%2F0972150914535145

Hakim, A. (2012). The Implementation of Islamic Leadership and Islamic Organizational Culture and Its Influence on Islamic Working Motivation and IslamicPerformance PT Bank Mu'amalat Indonesia Tbk. Employee in the Central Java. Asia Pacific Management Review, 17(1).

Ilham, R. (2018). The Impact of Organizational Culture and Leadership Style on Job Satisfaction and Employee Performance. Journal of Advanced Management Science, 6(1), 50-53.

Kawiana, I. G. P., Dewi, L. K. C., Martini, L. K. B., \& Suardana, I. B. R. (2018). The influence of organizational culture, employee satisfaction, personality, and organizational commitment towards employee performance. International Research Journal of Management, IT and Social Sciences, 5(3), 35-45.

Krisnanda, P. H., \& Surya, I. B. K. (2019). Effect of emotional and spiritual intelligence on transformational leadership and impact on employee performance. International Research Journal of Management, IT and Social Sciences, 6(3), 70-82. https://doi.org/10.21744/irjmis.v6n3.634

Krisnanda, P. H., \& Surya, I. B. K. (2019). Effect of emotional and spiritual intelligence on transformational leadership and impact on employee performance. International Research Journal of Management, IT and Social Sciences, 6(3), 70-82. https://doi.org/10.21744/irjmis.v6n3.634

Maamari, B. E., \& Saheb, A. (2018). How organizational culture and leadership style affect employees' performance of genders. International Journal of Organizational Analysis, 26(4), 630-651. https://doi.org/10.1108/IJOA-042017-1151

Mahal, P. K. (2009). Organizational Culture and Organizational Climate as a Determinant of Motivation. IUP Journal of Management Research, 8(10).

Manggis, I. W., Yuesti, A., \& Sapta, I. K. S. (2018). The Effect of Career Development and Organizational Culture to Employee Performance with Motivation of Work as Intervening Variable in Cooperation in Denpasar Village. International Journal of Contemporary Research and Review, 9(07), 20901-20916. https://doi.org/10.15520/ijcrr/2018/9/07/553

Na-Nan, K., Chaiprasit, K., \& Pukkeeree, P. (2018). Factor analysis-validated comprehensive employee job performance scale. International Journal of Quality \& Reliability Management, 35(10), 2436-2449. https://doi.org/10.1108/IJQRM-06-2017-0117

Narayana, A. (2017). A Critical Review of Organizational Culture on Employee Performance. American Journal of Engineering and Technology Management, 2(5), 72. https://doi.org/10.11648/j.ajetm.20170205.13

Obeidat, D., Yousef, B., Nofal, R., \& Masa'deh, R. E. (2018). The Effect of Transformational Leadership on Entrepreneurial Orientation: The Mediating Role of Organizational Learning Capability. Modern Applied Science, 12(11). 
Omollo, P. A., \& Oloko, M. A. (2015). Effect of motivation on employee performance of commercial banks in Kenya: A case study of Kenya Commercial Bank in Migori County. International journal of human resource studies, 5(2), 87-103. https://doi.org/10.5296/ijhrs.v5i2.7504

Pant, I., \& Yadav, R. K. (2016). Impact of emotional intelligence on the job performance of employee. International Research Journal of Management, IT and Social Sciences, 3(1), 7-14.

Pawirosumarto, S., Setyadi, A., \& Khumaedi, E. (2017). The influence of organizational culture on the performance of employees at University of Mercu Buana. International Journal of Law and Management, 59(6), 950-963. https://doi.org/10.1108/IJLMA-03-2016-0030

Pramudjono, P. (2015). Pengaruh Gaya Kepemimpinan, Tingkat Hierarki Moral, dan Motivasi terhadap Komitmen Guru. Cakrawala Pendidikan, (3).

Radakovich, P. S. (2016). The Relationship Between Organizational Culture, Intrinsic Motivation, And Employee Performance: A Systematic Review And Meta-Analysis.

Rasool, H. F., Arfeen, I. U., Mothi, W., \& Aslam, U. (2015). Leadership styles and its impact on employee's performance in health sector of Pakistan. City University Research Journal, 5(1), 97-109.

Sappe, S., Rante, Y., Tuhumena, R., \& Bharanti, B. E. (2016). Effect of Leadership on Employeeâ€TM s Performance Mediated by Cultural Organization, Work Commitment and Motivation. Journal of Economics and Behavioral Studies, 8(2), 101-107. https://doi.org/10.22610/jebs.v8i2.1258

Schultz, H., Bagraim, J., Potgieter, T., Viedge, C., \& Werner, A. (2003). Organisational behaviour: A contemporary South African perspective. Pretoria: Van Schaik.

Sihombing, S., Endang, S.A., Mussadieq, M., Djamhur, H., \& Kusdi, R. 2016. "The effect of servant leadership to rewards, organizational culture, and its implication to employee's performance". International Journal of Law and Management, 60(2), 505-516.

Siregar, A. R., Maulamin, T., \& Arifianto, I. (2016). The influence of leadership and motivation on employees performance of the national library of indonesia. International Journal of Management and Applied Science (IJMAS), 3(2), 7-9.

Sivakami, R., \& Samitha, S. S. (2018). A study on the impact of organizational culture on employee performance. International Journal of Management Research and Reviews, 8(7), 1-8.

Suwandana, I. G. M. (2019). Role of transformational leadership mediation: effect of emotional and communication intelligence towards teamwork effectiveness. International Research Journal of Management, IT and Social Sciences, 6(2), 52-62. https://doi.org/10.21744/irjmis.v6n2.608

Syafii, L. I., Thoyib, A., \& Nimran, U. (2015). The role of corporate culture and employee motivation as a mediating variable of leadership style related with the employee performance (studies in Perum Perhutani). Procedia-Social and Behavioral Sciences, 211, 1142-1147. https://doi.org/10.1016/j.sbspro.2015.11.152

Syaifuddin, S. A. (2016). The influence of work stress and transformational leadership on work motivation and implication of employee's performance (case study). Academy of Strategic Management Journal, 15(3), 42-48.

Thuku, R.W., Abiero I.O., \& Juma, D. 2016. Influence of organisational culture on employee performance: a case study of east african breweries limited. International Journal of Science and Research (IJSR), 5(9), $1500-1506$.

Tobing, D. S. K., \& Syaiful, M. (2018). The Influence Of Transformational Leadership And Organizational Culture On Work Motivation And Employee Performance At The State Property Service Office And Auction In East Java Province.

Ullah, R., Latif, K. F., \& Alam, W. (2018). Role of transformational leadership style on employee job performance among high and low ranking institutions of higher education of khyber pakhtunkhwa. City University Research Journal, 8(2), 168-189.

Yunita, P. I., \& Saputra, I. G. N. W. H. (2019). Millennial generation in accepting mutations: Impact on work stress and employee performance. International Journal of Social Sciences and Humanities, 3(1), 102-114. https://doi.org/10.29332/ijssh.v3n1.268

Putra, G. N. S., \& Dewi, I. G. A. M. (2019). Effect of transformational leadership and organizational culture on employee performance mediated by job motivation. International Research Journal of Management, IT and Social Sciences, 6(6), 118-127. https://doi.org/10.21744/irjmis.v6n6.778 